\title{
Forest Schools: An Alternative Learning Approach at the Preschool Age
}

\author{
Vasiliki Karavida \\ Eleni Tympa \\ Assistant Professor, Department of Early Years Learning and Care \\ University of Ioannina, Ioannina \\ Greece \\ Athina Charissi \\ Lecturer, Department of Early Years Learning and Care \\ University of Ioannina, Ioannina \\ Greece
}

\begin{abstract}
Children's outdoor play is declining despite the clear interaction between play, learning and child development. Therefore, the children need alternative forms of learning that, among other things, provide them with the opportunity to play outdoors. Forest schools recommend a pedagogical process that takes place in the natural environment, outside the narrow boundaries of the classroom, and seek free, unrestricted learning by promoting the child's all-round development. Especially for preschool children, their social, motor and mental development is achieved in an experimental way. They combine the pedagogical program, the contract with nature, the research in early childhood and individualized learning opportunities. Learning outdoors can have a positive impact on the physical, cognitive and socio-emotional development of young children.
\end{abstract}

Keywords: forest school, early years, outdoor play, learning outdoor, child development

\section{Forest Schools as a learning model}

Playing in the mud, climbing and generally playing in nature are activities that give children pleasure and are intertwined with childhood. In modern times, however, these activities tend to fade away. Parents in most cases do not help in order to change this situation. Instead, they often scold children when they get dirty playing in the park or the playground. Playing outdoors though is in the nature of the child (Kostic, 2016).

The welfare of children should be the cornerstone of every educational process. Forest school programs aim to promote the holistic development of the child. Education that takes place outside the confines of the classroom is considered to provide more memorable and stimulating learning experiences, as it instills interest, enthusiasm and motivation for knowledge in childhood (Harris, 2018).

\section{The origin and dissemination of the method}

The forest school method was initiated in 1927 by an individual teacher in America, but has involved in the Nordic countries since 1950 and became part of the Danish detailed curriculum in the early 1980s. It's goal was to use forests in education as an essential element of the child's development. In the early 1990s the method began to spread in the United Kingdom (Bradley \& Male, 2017).

Forest kindergartens in Germany were recognized as a form of child care in 1960 and today Germany has the most established program in the world, with more than 700 forest kindergartens. Independent forest schools operate successfully in the USA, Asia, Australia and European countries, including Greece (www. Happyacresforestscool.com/).

\section{Defining forest schools}

Forest schools are a child-centered approach to education based on nature and the environment with the emphasis laid on forests and the natural, spontaneous exploration on the part of children. It takes place exclusively outdoors and under any weather conditions. It is a learning philosophy based on the child and emphasizes on all senses. For children between 3 and 6 years old, the term forest nursery school is often used. The role of the educator is to help children and not guide them. 
Their characteristic is the emphasis given on playing with objects that children find in the natural environment (Gregory, 2017). It is about an educational process of frequent sessions that lasts a long time and involves the same group of children (Austin, Knowles, \& Sayers, 2013). The fundamental idea of a forest school is to create opportunities for children to spend more time playing and, at the same time, learning in the natural environment (MacEachren, 2013).

Forest schools in the United Kingdom have been defined as "an inspiring process that offers children, youngsters and adults regular opportunities to succeed and develop confidence through empirical learning in a forest environment" (O’Brien \& Murray, 2006, p. 4).

According to Leather (2018) "the forest school is a form of outdoor education that is mainly related to education in early childhood (children between 3 and 8), when children spend their time in forest areas" (p. 2).

Turtle, Convery and Convery (2015) define forest schools as a philosophy of education that "generally follows a holistic approach to learning, is normally conducted in a natural and wild place, such as a forest, and is guided by the child" (p. 2).

Elliot and Chancellor (2014) argue that "the key feature of the forest preschool approach is that children spend long and regular periods of time, weekly or daily, in unstructured play that takes place in natural forests or coastal environments throughout the years" (p. 46).

\section{The philosophy and curriculum of forest schools}

The curriculum followed is guided by children and it is based on play. Forest schools give children the time and the place to unfold their interests and skills and apprehend them through practical experiences. Children have the freedom to explore, play, build, create, imagine and use their senses so as to experience the external environment and interact with each other. The sessions are carefully designed, they are guided by trained educators and they are conducted outside the classroom, in a forest, mountain, sea shore, etc. During these sessions, children can sing, learn how to use and construct tools, build and dig in the mud, converse.

All participants in a forest school are regarded as equal with each other, capable of exploring and discovering, entitled to confront dangers and challenges; they can make friends with any of the children they wish and they have the right to choose, initiate and guide the learning process (Kostic, 2016).

\section{Basic principles governing forest schools}

The forest school is based on six basic principles:

- It is a long standing process with regular and repeated sessions in a natural, mainly forest environment, and not a one-time visit. Planning, adaptation, observation and review are integral elements of forest schools.

- They take place in a forest environment with the aim of developing the relationship between learner and natural environment.

- Their goal is to promote the holistic development of all those involved making them resilient, independent and creative.

- Forest schools give children the opportunity to take risks, within their potential.

- They are under the supervision and guidance of specialized educators.

- They employ a series of child-centered procedures aimed at their all-round development (Cree \& McCree, 2013; Waller et al., 2017).

\section{Characteristics of forest schools}

The basic characteristics of forest schools, generally, can be described as:

- The use of a forest area with defined boundaries that allow the versatility and freedom of children aiming at innovative approaches in a safe way.

- Large proportion of educators to children. The groups they participate in are small, which gives children the opportunity to take initiatives and engage in activities that arouse their interest but not expose them to danger. Additionally, it gives educators the opportunity to get to know the individual skills of children.

- Learning in the natural environment is associated with the objectives of the preschool curriculum. By integrating alternative learning approaches (such as undertaking small and easily achievable tasks), children are encouraged to develop their innate curiosity for learning. This is especially helpful for children who have difficulty learning in a strict "classroom" environment.

- The freedom of exploration through all the senses is fundamental in encouraging creative and imaginary play. The focus is on "the child as a whole" and how he can develop his personal learning skills at his own pace. 
- Regular sessions for a considerable period of time and in all weather conditions. This presupposes specific routines as well as safety boundaries that allow children to develop a responsible attitude towards risk, while, at the same time, they become familiar and confident with the ever-changing natural environment (Cree \& McCree, 2013; O’Bien \& Murray, 2006).

\section{Pedagogical approaches}

Forest schools focus on the child and aim at his holistic development and apprehension of the world around him. In particular, the curriculum of forest schools focuses on the following approaches:

- Experiential learning. Children have an innate curiosity to explore their surroundings, discuss their experiences and then learn by doing things on their own. The main role of the educator is to support children's activities in the natural environment. Experiential learning focuses on reinforcing the interests of every child, while their participation in small groups enhances their sociability and ability to solve problems.

- Learning through play. Play-based learning focuses on the child's all-round development, as outdoor play requires the use of all his senses. In addition, children develop problem-solving skills as well as collaboration skills.

- Learning based on space (place). Forest schools seek to promote the long-term connection of children to specific natural location, as when children are attached to a specific place, they acquire a sense of ownership and the responsibility to protect it.

- Story-telling. Story telling is an integral part of the school educational process. Through story telling children learn, have fun and enrich their vocabulary.

- Playing with "loose parts materials". There is a big range of materials in a forest area, such as stones, soil, sticks, leaves, weeds, seeds, etc. The specific materials give innumerable opportunities to expand creativity and imagination (Coates \& Pimlott-Wilson, 2019; Forest School Association, 2018; Blackwell, n.d.; Sobel et al., 2014; Hughes, 2013).

\section{Resulting benefits for children}

According to research, forest schools have numerous benefits for the physical, cognitive and socio-emotional development of children.

\subsection{Physical benefits}

Physical activity is essential for young children so as to have a healthy growth (World Health Organization (WHO), 2019). Running and climbing up tree trunks develops children's muscular strength, visual-motor coordination and gross mobility, while at the same time relieves them from excess energy. Children develop physical characteristics, such as sense of balance, stamina and agility. Additionally, their engagement and creation of "works of art" with natural materials such as leaves, soil, sticks, stones, improve their fine mobility (Coates \& Pimlott-Wilson, 2019; MacEachren, 2013).

Moreover, children playing outdoors and getting in contact with micro-orgasms found in the soil boosts the levels of serotonin, a chemical substance associated with mental health, while vitamin D intake is essential for the healthy condition of their bones and muscles (Forest School: 9 ways children benefit from learning and playing outside, 2018).

\subsection{Cognitive benefits}

The external environment is often referred to as a "unique learning environment", as it instills enthusiasm, interest and motivation for learning. Young children learn better and more easily through experience (experiential learning). In forest schools children develop skills such as decision taking, planning and setting goals. Through communication and collaboration with the children of the group, they expand their vocabulary. Nature gives children countless opportunities to pose questions and converse with their educators and peers. Forest pedagogy motivates children to step out of the comfort of the classroom, face challenges and develop skills they must accomplish. The objects in the classroom are usually related to common usage patterns. In the countryside, children learn how to exploit natural objects and invent ways to use them, by keeping their thinking, imagination and creativity alert (Nawaz \& Blackwell, 2014; Harris, 2018; Waller et al., 2017).

\subsection{Socio-emotional benefits}

Playing in nature boosts children's self-esteem and confidence, while it enhances their self-discipline. 
Children participate is less corrected and therefore more impulsive learning, with greater freedom to interact with each other and choose their "partners", thus encouraging pre-school behavior, which will have a positive impact on their social relationships. Their contact with the natural environment has a positive effect on the children's resilience, selfregulation of emotions and reduction of stress levels in the body. Children also learn how to respect and protect the natural environment (Coraliza, Collado, \& Bethelmy, 2012; Nawaz \& Blackwell, 2014; Whitebread, 2017).

Lastly, in the natural environment children do not need to stifle energy, motion and noise levels, as it is necessary in preschool settings. This reduces the need for children to control and suppress their imagination and actions, which is often stressful for children (Harris, 2018).

\section{Conclusions}

Forest schools are an innovative child-centered pedagogical approach with a positive impact on children's learning, development, resilience, trust and welfare. Learning outdoors enhances the personal, social and emotional development of children, through teamwork and their acquiring social and communication skills.

Children strengthen their resilience while being given learning opportunities where they can participate in decision taking and engage in activities of their choice. Forest school curriculum encourages children to develop positive relationships with educators, peers and also parents, enhancing in this way their sociability.

Through forest schools children's self-confidence improves. They are therefore willing to take calculated risks and try new experiences, where they will have the opportunity to use their skills and acquire new ones.

Play in the countryside is essential for the physical growth of children and offers opportunities for physical activity, contributing therefore to reducing overweight, and growing into a strong and agile body. In addition, interaction with nature contributes to the psychological and mental well-being of children, allows their familiarity with the natural environment, reinforces their love for it and consequently their positive attitude towards the environment.

\section{References}

Austin, C., Knowles, Z., \& Sayers, J. (2013, December). Investigating the effectiveness of Forest School sessions on children's physical activity levels

.https://www.merseyforest.org.uk/files/documents/1341/Austin,\%20C.,\%20Knowles,\%20Z.\%20and\%20Sayer s,\%20J.\%20Forest\%20School\%20Evaluation.pdf

Blackwell, S. (n.d.). Impacts of Long Term Forest School Programmes on Children's Resilience, Confidence and Wellbeing. file:///C:/Users/User/Desktop/Forest\%20School/impacts-of-long-term-forest-schools-programmeson-childrens-resilience-confidence-and-wellbeing.pdf

Bradley, K., \& Male, D. (2017). 'Forest School is muddy and I like it': Perspectives of young children with autism spectrum disorders, their parents and educational professionals. Educational and Child Psychology, 34(2), 8096

Coates, J. K., \& Pimlott-Wilson, H. (2019). Learning while playing: Children's Forest School experiences in the UK. British Educational Research Journal, 45(1), 25-40. https://doi.org/10.1002/berj.3491

Corraliza, J. A., Collado, S., \& Bethelmy, L. (2012). Nature as a Moderator of Stress in Urban Children. Procedia Social and Behavioral Sciences, 38, 253-263. https://doi.org/10.1016/j.sbspro.2012.03.347

Cree, J., \& McCree, M. (2013). A brief history of forest school in the UK - Part 2. Horizons Magazine, 62, 32-35

Elliott, S., \& Chancellor, B. (2014). From forest preschool to Bush Kinder: An inspirational approach to preschool provision in Australia. Australasian Journal of Early Childhood, 39(4), 45-53. https://doi.org/10.1177/183693911403900407

Forest School Association. (2018). What is Forest School? www.forestschoolassociation.org/what-is-forest-school

Forest School: 9 ways children benefit from learning and playing outside. (2018, June). https://home.bt.com/lifestyle/health/wellness/forest-school-9-ways-children-benefit-from-learning-andplaying-outside-11364276783242

Gregory, A. (2017, May). Running Free in Germany's Outdoor Preschools. The New York Times Style Magazine.https://www.nytimes.com/2017/05/18/t-magazine/germany-forest-kindergarten-outdoor-preschoolwaldkitas.html?_r=0

Harris, F. (2018). Outdoor learning spaces: The case of forest school. Area, 50(2), 222-231. https://doi.org/10.1111/area.12360

Hughes, B. (2013). Evolutionary Playwork (2 ${ }^{\text {nd }}$ ed.). London: Routledge. https://doi.org/10.4324/9780203873830

Kostic, M. (2016). Forest Schools: A philosophy of child led learning. $\Delta 1 \alpha \theta \dot{\varepsilon} \sigma \mu \mathrm{o} \sigma \tau \mathrm{o}$ : https://novakdjokovicfoundation.org/forest-schools-child-led-learning/ 
Leather, M. (2018). A critique of "Forest School" or something lost in translation. Journal of Outdoor and Environmental Education, 21(1), 5-18. https://doi.org/10.1007/s42322-017-0006-1

MacEachren, Z. (2013). The Canadian Forest School Movement. LEARNing Landscapes, 7(1). https://doi.org/10.36510/learnland.v7i1.639

Nawaz, H., \& Blackwell, S. (2014). Perceptions about forest schools: Encouraging and promoting Archimedes Forest Schools. Educational Research and Reviews, 9(15), 498-503. https://doi.org/10.5897/err2014.1711

O’ Brien, L., \& Murray, R. (2006). A marvelous opportunity for children to learn. A participatory evaluation of Forest School in England and Wales. file:///C:/Users/User/AppData/Local/Temp/fr0112forestschoolsreport.pdf

Sobel, D., Andrachuk, H., Edgar, T., Eperjes, P., Filler, C., Groves, J., Kaknevicius, J., Lahton, R., Mason, J., Molyneux, L., Mprcom, L., Petrini, G., Piersol, L., Power, M., \& Young, J. (2014, June). Forest and Nature School in Canada: A Head, Heart, hands Approach to Outdoor Learning. http://childnature.ca/wpcontent/uploads/2017/10/FSC-Guide-1.pdf

Turtle, C., Convery, I., \& Convery, K. (2015). Forest schools and environmental attitudes: A case study of children aged 8-11 years. Cogent Education, 2, 1100103. https://doi.org/10.1080/2331186X.2015.1100103

Waller, T., Ärlemalm-Hagsér, E., Sandseter, E., Lee-Hammond, L., Lekies, K., \& Wyver, S. (2017). The SAGE Handbook of Outdoor Play and Learning. https://books.google.gr/books?id=PKMoDwAAQBAJ\&printsec=frontcover\&hl=el\&source=gbs_ge_summary r $\&$ cad $=0 \# \mathrm{v}=$ onepage $\& \mathrm{q} \& \mathrm{f}=$ false

Whitebread, D. (2017). Free play and children's mental health.The Lancet Child \& Adolescent Health, 1(3), 167-169. https://doi.org/10.1016/S2352-4642(17)30092-5

What are Forest Schools (n.d.). https://www.happyacresforestschool.com/

World Health Organization. (2019). Guidelines on physical activity, sedentary behaviour and sleep for children under 5 years of age. World Health Organization. https://apps.who.int/iris/handle/10665/311664. 